\title{
Correction: Perceptions of risk for COVID-19 among individuals with chronic diseases and stakeholders in Central Appalachia
}

\author{
Manik Ahuja D, Hadii M. Mamudu, Florence M. Weierbach, Karilynn Dowling-McClay, David W. Stewart,
} Manul Awasthi \& Timir K. Paul

Correction to: Humanities and Social Sciences Communications https://doi.org/10.1057/s41599-021-00906-7, published online 7 October 2021.

The original paper lacked a clear statement on ethical approval and informed consent. The following statements have now been added to the paper to provide additional clarity for the reader:

Ethical approval

The research is part of an East Tennessee State University Institutional Review Board PCORI approved protocol that embodies the protection of human subjects.

Informed consent

The research is part of an East Tennessee State University Institutional Review Board PCORI approved protocol that embodies informed consent.

Published online: 16 November 2021

Open Access This article is licensed under a Creative Commons Attribution 4.0 International License, which permits use, sharing, adaptation, distribution and ceproduction in any medium or format, as long as you give appropriate credit to the original author(s) and the source, provide a link to the Creative Commons license,
and indicate if changes were made. The images or other third party material in this article are included in the article's Creative Commons license, unless indicated otherwise in a credit line to the material. If material is not included in the article's Creative Commons license and your intended use is not permitted by statutory regulation or exceeds the permitted use, you will need to obtain permission directly from the copyright holder. To view a copy of this license, visit http://creativecommons.org/licenses/by/4.0/.

(๑) The Author(s) 2021 